\title{
Albuminuria in Type 2 (non-insulin-dependent) diabetes mellitus and impaired glucose tolerance in Pima Indians
}

\author{
R.G. Nelson, C.L.Kunzelman, D.J.Pettitt, M.F.Saad, P.H. Bennett and W.C. Knowler \\ Diabetes and Arthritis Epidemiology Section, National Institute of Diabetes and Digestive and Kidney Diseases, Phoenix, Arizona, USA
}

\begin{abstract}
Summary. The prevalence of abnormal urinary albumin excretion, defined by a urine albumin to creatinine ratio $\geq 30 \mathrm{mg} / \mathrm{g}$ (approximately equivalent to an albumin excretion rate of $\geq 30 \mathrm{mg} / 24 \mathrm{~h}$ ), was determined in 2728 Pima Indians aged $\geq 15$ years from the Gila River Indian Community in Arizona, a population with a high prevalence of Type 2 (non-insulindependent) diabetes mellitus. Excessive albumin excretion was present in $8 \%$ of subjects with normal glucose tolerance, $15 \%$ of those with impaired glucose tolerance, and $47 \%$ of subjects with diabetes. The intermediate prevalence of abnormal albuminuria in those with impaired glucose tolerance suggests that hyperglycaemia even at levels below those diagnos-
\end{abstract}

tic of diabetes is associated with renal abnormalities in some subjects and that these abnormalities may precede the onset of diabetes. Abnormal albuminuria at levels not reliably detected by the usual dipstick methods was commonly observed in Pima Indians with diabetes, even those with diabetes of recent onset. Associations were found with age, duration of diabetes, level of glycaemia, blood pressure, and treatment with insulin.

Key words: Albuminuria, prevalence, diabetic nephropathy, Type 2 (non-insulin-dependent) diabetes mellitus, impaired glucose tolerance, American Indians.
Renal disease is a major cause of morbidity and mortality in persons with diabetes, and renal failure secondary to Type 2 (non-insulin-dependent) diabetes mellitus accounts for the majority of patients with diabetes enrolled in end-stage renal disease programmes in the United States [1]. Although end-stage renal disease is more frequent in Type 1 (insulin-dependent) than in Type 2 diabetes, recent studies suggest that the incidence of nephropathy and end-stage renal disease in both types of diabetes may not differ when persons with similar diabetes duration are compared [2-4].

Previous studies have shown that albumin excretion in excess of normal, but at concentrations not reliably detected by the usual clinical methods (sometimes referred to as "microalbuminuria"), predicts the development of clinical diabetic renal disease $[5,6]$. Moreover, the detection of such degrees of albuminuria may allow recognition of diabetic renal disease at a stage when the pathogenetic process may be reversible or at which progression may be slowed [7-15].

In the present study the prevalence of abnormal albumin excretion was determined in the Pima Indians of Arizona, a population in which Type 1 diabetes is unknown [16], but in which approximately half develop Type 2 diabetes [17]. Urinary albumin concentrations were measured with a nephelometric immunoassay using a monospecific antiserum to human albumin. Relationships of albuminuria to glucose tolerance and other factors were examined.

\section{Subjects and methods}

As part of a longitudinal study of diabetes and its complications conducted by the National Institutes of Health in the Gila River Indian Community of Arizona [18], oral glucose tolerance tests were performed and albumin excretion measured between July 1, 1982 and June 30,1988 in 2728 subjects aged $\geq 15$ years whose heritage was at least $50 \%$ Pima, Papago, or a mixture of these two closely related tribes. The population census on January 1, 1985, the approximate midpoint of the study, indicated that there were 3357 Pima Indians (1649 men, 1708 women) aged $\geq 15$ years living within the community. The glucose concentration was determined in venous plasma drawn $2 \mathrm{~h}$ after the ingestion of a $75-\mathrm{g}$ carbohydrate load (Glucola, Ames Company, Elkhart, Ind, USA; Dexcola, Custom Laboratories, Baltimore, Md, USA; or Koladex, Custom Laboratories, Baltimore, Md, USA). According to World Health Organization criteria [19], diabetes was diagnosed when the $2 \mathrm{~h}$ post-load plasma glucose concentration was $\geq 11.1 \mathrm{mmol} / 1$, and impaired glucose tolerance when the glucose concentration was $<11.1 \mathrm{mmol} / \mathrm{l}$ but $\geq 7.8 \mathrm{mmol} / \mathrm{l}$. The date of diagnosis of diabetes was determined from these or previous research examinations, or from review of clinical records if diabetes was diagnosed in the course of routine medical care. 
Table 1. Clinical features of study population

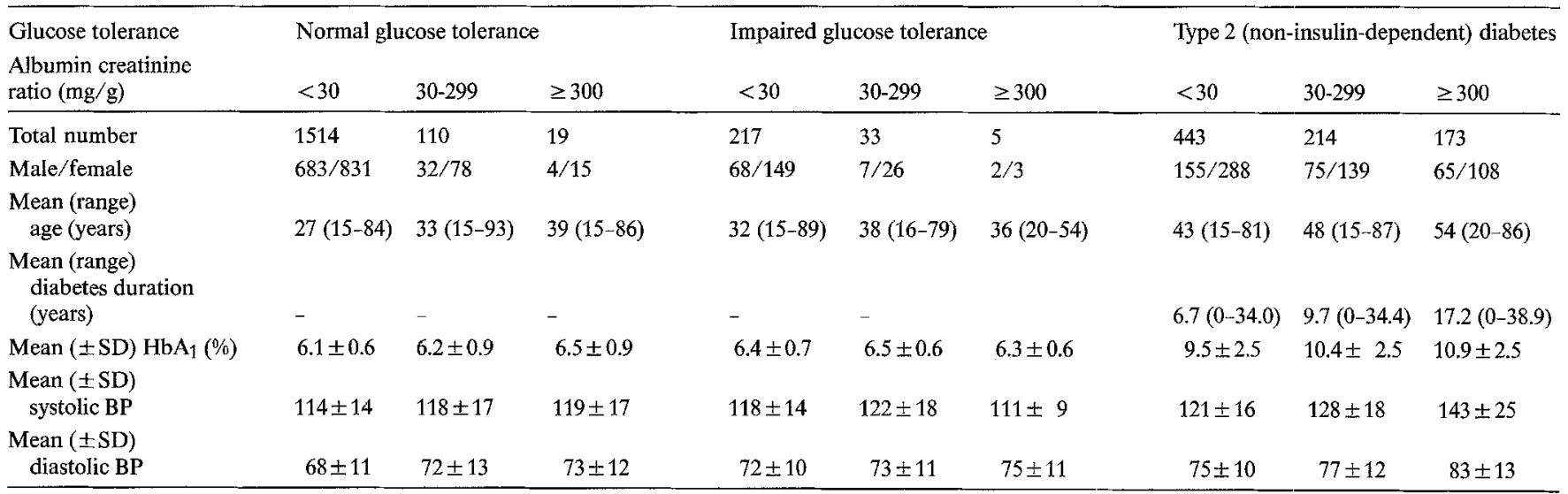

$\mathrm{BP}=$ Blood pressure $(\mathrm{mm} \mathrm{Hg})$

Subjects were asked to empty their bladders at the beginning of the oral glucose tolerance test, and a urine specimen was collected $2 \mathrm{~h}$ later. These collections were made predominately between 08.00 and 12.00 hours. Specimens were frozen, stored at $-20^{\circ} \mathrm{C}$, and assayed within 30 days for albumin concentration with a nephelometric immunoassay using a monospecific antiserum to human albumin [14] and for creatinine concentration using the Jaffe method [20] as modified by Chasson et al. [21]. A urinary albumin to urinary creatinine ratio ( $\mathrm{mg}$ albumin/g creatinine) was used as an estimate of albumin excretion rate [22-25]. Urinary albumin excretion was considered to be abnormal if the albumin to creatinine ratio was $\geq 30 \mathrm{mg} / \mathrm{g}$. This level is approximately the 95 th percentile of urinary albumin to creatinine ratios in a "healthy" subset of the Pima Indian population aged $\geq 15$ years who had normal glucose tolerance, took no medicines, had no known renal or cardiovascular diseases, and had normal blood pressures (systolic blood pressure $<160 \mathrm{~mm} \mathrm{Hg}$, diastolic blood pressure $<95 \mathrm{~mm} \mathrm{Hg}$ ) and normal serum creatinine concentrations [ $<133 \mu \mathrm{mol} / 1$ ] [unpublished observations]. A second level of abnormality was arbitrarily defined at an albumin to creatinine ratio of $300 \mathrm{mg} / \mathrm{g}$, corresponding approximately to dipstick detectable $(\geq 1+)$ proteinuria that has traditionally been taken to represent "clinical proteinuria" in many studies of diabetic renal disease.

Blood pressure was measured with a mercury sphygmomanometer with subjects at rest in a supine position. Diastolic blood pressure was measured at the fourth Korotkoff sound to the nearest $2 \mathrm{~mm} \mathrm{Hg}$. Mean blood pressure was defined as two-thirds the diastolic blood pressure plus one-third the systolic blood pressure. Plasma glucose was measured by the ferricyanide method with an Autoanalyser [26]. $\mathrm{HbA}_{1}$ was measured by agar gel electrophoresis [27].

\section{Statistical analysis}

Chi-square tests for association were performed by the Mantel-Haenszel method [28]. The effects of continuous variables were evaluated with a Chi-square test by grouping the values of the variables and assessing average partial association in three-way contingency tables under the multiple hypergeometric model while controlling for the effects of a set of covariables [29].

Multiple logistic regression analysis [30] was used to test several models of the association of excessive albuminuria with glucose tolerance and other variables. The results of the parsimonious models, controlling for potential confounding variables, are presented. As significant interactions between sex and glucose tolerance, and sex and age were found in the analysis of subjects with diabetes or normal glucose tolerance, separate models for men and women are presented. In addition, a model testing the relative association of several variables with excessive albuminuria in persons with diabetes is shown.
Covariate-adjusted prevalence rates of excessive albuminuria according to different durations of diabetes and levels of mean blood pressure were calculated from the regression model by covariance adjustment of rates to the mean values of the covariates in the sample [31].

\section{Results}

Of the 2728 subjects (1091 men, 1637 women), 255 (77 men, 178 women) had impaired glucose tolerance and 830 ( 295 men, 535 women) had Type 2 diabetes (Table 1). Urinary albumin to creatinine ratios of 30 -

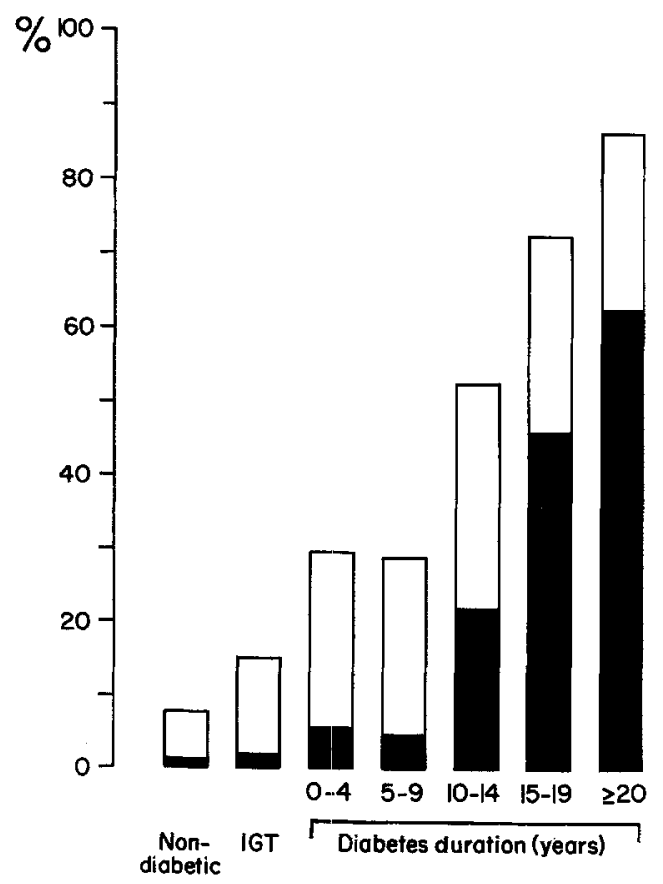

Fig.1. Prevalence (\%) of albuminuria in Pima Indians according to glucose tolerance in non-diabetic subjects and diabetes duration in Type 2 (non-insulin-dependent) diabetic subjects. Normal glucose tolerance: $2 \mathrm{~h}$ glucose $<7.8 \mathrm{mmol} / \mathrm{l}$; impaired glucose tolerance (IGT): $2 \mathrm{~h}$ glucose $\geq 7.8 \mathrm{mmol} / 1$ but $<11.1 \mathrm{mmol} / 1$; Type 2 diabetes: $2 \mathrm{~h}$ glucose $\geq 11.1 \mathrm{mmol} / 1$. Urine albumin/creatinine $(\mathrm{mg} / \mathrm{g}): 30-299$ (ㅁ); $\geq 300(\mathbf{\square})$ 


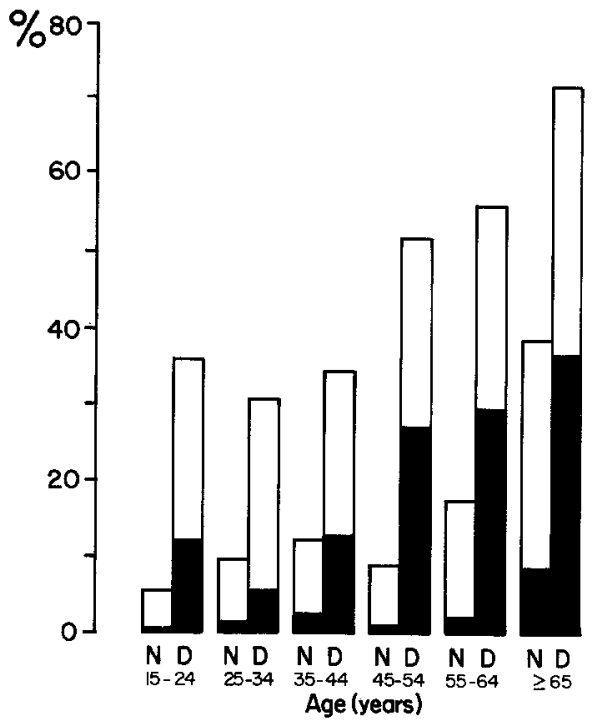

Fig. 2. Prevalence (\%) of albuminuria according to age in nondiabetic (N) and in Type 2 (non-insulin-dependent) diabetic (D) Pima Indians. Urine albumin/creatinine (mg/g): 30-299 ( $\square$ ); $\geq 300$ (ם)

$299 \mathrm{mg} / \mathrm{g}$ were found in $7 \%$ of subjects with normal glucose tolerance, $13 \%$ of those with impaired glucose tolerance, and $26 \%$ of subjects with Type 2 diabetes; higher urinary albumin to creatinine ratios $(\geq 300 \mathrm{mg} / \mathrm{g}$ ) were present in $1 \%$ of subjects with normal glucose tolerance, $2 \%$ of subjects with impaired glucose tolerance, and $21 \%$ of subjects with Type 2 diabetes. Among subjects with urine albumin to creatinine ratios of $30-299 \mathrm{mg} / \mathrm{g}$, only $20 \%$ had dipstick (Labstix, Ames Company, Elkhart, Ind, USA) positive proteinuria $(\geq 1+)$, while $89 \%$ of those with ratios $\geq 300 \mathrm{mg} / \mathrm{g}$ were dipstick positive. Albumin concentration in the urine was below the sensitivity of the assay $(<2 \mathrm{mg} / 1)$ in $12 \%$ of those with normal glucose tolerance, $10 \%$ of those with impaired glucose tolerance, and $5 \%$ of those with Type 2 diabetes. The urinary albumin to creatinine ratio could not be calculated in these subjects and the albumin excretion was assumed to be in the normal range.

Figure 1 shows the prevalence of abnormal urinary albumin excretion according to glucose tolerance status. The prevalence of abnormal albuminuria differed between the three categories of glucose tolerance $\left(x^{2}=194.7, \mathrm{df}=2, p<0.001\right.$, stratified by age and sex), and was greater in subjects with impaired than in those with normal glucose tolerance. Type 2 diabetic subjects, even those of short diabetes duration, had higher prevalence rates than did those with either impaired or normal glucose tolerance. The prevalence of abnormal albumin excretion in Type 2 diabetic subjects was related to the duration of diabetes and was $29.4 \%$ in those with $0-4$ years duration of diabetes and $86.4 \%$ in those with at least 20 years duration.

In subjects with normal glucose tolerance, women had a significantly higher prevalence of abnormal albuminuria than men $\left(x^{2}=14.8, \mathrm{df}=1, p<0.001\right.$, stratified by age), but no gender difference was found in subjects with impaired glucose tolerance or diabetes. The prevalence of abnormal albuminuria increased significantly with age regardless of glucose tolerance (normal, impaired, or diabetes) $\left(x^{2}=105.6, \mathrm{df}=5, p<0.001\right.$, stratified by sex and glucose tolerance). Figure 2 shows the prevalence of excessive albuminuria according to age in Type 2 diabetic and non-diabetic subjects.

Nineteen subjects with normal glucose tolerance ( 4 men, 15 women) and five with impaired glucose tolerance ( $2 \mathrm{men}, 3$ women) had urine albumin to creatinine ratios $\geq 300 \mathrm{mg} / \mathrm{g}$. Among these subjects, clinical records revealed that 10 (8 with normal and 2 with impaired glucose tolerance) had suffered from recurrent urinary tract infections and/or pyelonephritis; 6 (all with normal glucose tolerance) had chronic glomerulonephritis; 1 (with normal glucose tolerance) had systemic lupus erythematosus; and 7 (4 with normal and 3 with impaired glucose tolerance) had albuminuria of unknown aetiology. Evaluation for kidney

Table 2. Multiple logistic regression models in Pima Indians according to categories of glucose tolerance

\begin{tabular}{|c|c|c|c|c|}
\hline \multicolumn{5}{|c|}{ Dependent variable: Albuminuria $\geq 30 \mathrm{mg} / \mathrm{g}$} \\
\hline Variable & $\beta$ & SE of $\beta$ & $x^{2}$ & $p$ \\
\hline \multicolumn{5}{|c|}{ Comparison of impaired and normal glucose tolerance $n=1889^{\mathrm{a}}$} \\
\hline Age (years) & 0.0473 & 0.0089 & & \\
\hline Age $\times \operatorname{Sex}^{\mathrm{c}}$ & -0.0347 & 0.0112 & & \\
\hline $\begin{array}{l}\text { Sex }(\text { women }=1, \\
\text { men }=0)\end{array}$ & 2.1523 & 0.4566 & $33.60^{\mathrm{d}}$ & $<0.001$ \\
\hline $\begin{array}{l}\text { pressure } \\
\text { Glucose tolerance }\end{array}$ & 0.0338 & 0.0084 & 16.23 & $<0.001$ \\
\hline $\begin{array}{l}\text { (impaired }=1 \\
\text { normal }=0) \\
\text { Intercept }\end{array}$ & $\begin{array}{r}0.3799 \\
-7.4981\end{array}$ & $\begin{array}{l}0.2089 \\
0.8196\end{array}$ & 3.31 & 0.069 \\
\hline
\end{tabular}

Comparison of men with Type 2 (non-insulin-dependent) diabetes and normal glucose tolerance $n=1011^{\text {a }}$

$\begin{array}{lrrrr}\begin{array}{l}\text { Age (years) } \\ \text { Mean blood } \\ \text { pressure }\end{array} & 0.0367 & 0.0069 & 28.04 & <0.001 \\ \begin{array}{c}\text { Glucose tolerance } \\ \quad \text { (diabetes=1, }\end{array} & 0.0427 & 0.0085 & 25.06 & <0.001 \\ \quad \text { normal=0) } & 1.9885 & 0.2280 & 76.07 & <0.001 \\ \begin{array}{l}\text { Intercept } \\ \text { C. }\end{array} & -7.9727 & 0.8283 & & \end{array}$

Comparison of women with Type 2 diabetes and normal glucose tolerance $n=1452^{\mathrm{a}}$

\begin{tabular}{|c|c|c|c|c|}
\hline Age (years) & -0.0550 & 0.0251 & \multirow{2}{*}{$31.29^{b}$} & \multirow{2}{*}{$<0.001$} \\
\hline $\begin{array}{l}\text { Age }^{2}\left(\text { years }^{2}\right) \\
\text { Mean blood }\end{array}$ & 0.0009 & 0.0003 & & \\
\hline $\begin{array}{l}\text { pressure }^{\mathrm{e}} \\
\text { Glucose tolerance }\end{array}$ & 0.0439 & 0.0070 & 39.76 & $<0.001$ \\
\hline $\begin{array}{l}\text { (diabetes }=1 \\
\text { normal }=0 \text { ) }\end{array}$ & 1.3943 & 0.1800 & 59.99 & $<0.001$ \\
\hline Intercept & -5.0889 & 0.6681 & & \\
\hline
\end{tabular}

a Nine subjects were excluded from the comparison of impaired and normal glucose tolerance due to missing values; three from the comparison of men with Type 2 diabetes and normal glucose tolerance; and seven from the comparison of women with Type 2 diabetes and normal glucose tolerance. ${ }^{b} x^{2}$ test for effect of age $(\mathrm{df}=2)$ derived from comparing this model with the model omitting both age terms. ${ }^{c}$ Interaction between age and sex. ${ }^{\mathrm{d}} x^{2}$ test for effect of sex $(\mathrm{df}=2)$ derived from comparing this model with the model omitting both sex terms. ${ }^{e}[(2 \times$ diastolic blood pressure $)+$ systolic blood pressure $] / 3$ 
Table 3. Multiple logistic regression model in Type 2 (non-insulindependent) diabetic Pima Indians

\begin{tabular}{|c|c|c|c|c|}
\hline \multicolumn{3}{|c|}{ Dependent variable: Albuminuria $\geq 30 \mathrm{mg} / \mathrm{g}$} & \multicolumn{2}{|c|}{$n=759^{\mathrm{a}}$} \\
\hline Variable & $\beta$ & SE of $\beta$ & $x^{2}$ & $p$ \\
\hline Age (years) & -0.0890 & 0.0349 & & 0 \\
\hline $\operatorname{Age}^{2}\left(\right.$ years $\left.^{2}\right)$ & 0.0010 & 0.0004 & & 0.0 \\
\hline $\begin{array}{l}\text { Sex }(\text { women }=1 \\
\text { men }=0)\end{array}$ & -0.0007 & 0.1863 & 0.00 & 0.997 \\
\hline $\begin{array}{l}\text { Type } 2 \text { diabetes } \\
\text { duration (years) }\end{array}$ & -0.1968 & 0.1102 & & \\
\hline $\begin{array}{l}\text { Type } 2 \text { diabetes } \\
\left.\text { duration }{ }^{2} \text { (years }{ }^{2}\right)\end{array}$ & 0.0034 & 0.0016 & $49.74^{\mathrm{c}}$ & $<0.001$ \\
\hline $\begin{array}{l}\text { Duration } \times \\
\text { blood pressure }^{d}\end{array}$ & 0.0022 & 0.0010 & & \\
\hline $\begin{array}{l}\text { Mean blood } \\
\text { pressure }\end{array}$ & 0.0244 & 0.0118 & $47.11^{\mathrm{e}}$ & $<0.001$ \\
\hline $\mathrm{HbA}_{1}(\%)^{\mathrm{g}}$ & 1.4870 & 0.3411 & 19.00 & $<0.001$ \\
\hline $\begin{array}{l}\text { Insulin treatment } \\
\quad(\text { yes }=1, \text { no }=0)\end{array}$ & 0.6429 & 0.2349 & 7.49 & 0.006 \\
\hline Intercept & -4.7570 & 1.4191 & & \\
\hline
\end{tabular}

${ }^{a}$ Seventy-one subjects were excluded due to missing values. ${ }^{b} x^{2}$ test for effect of age $(\mathrm{df}=2)$ derived from comparing this model with the model omitting both age terms. ${ }^{c} x^{2}$ test for effect of duration $(\mathrm{df}=3)$ derived from comparing this model with the model omitting all terms involving duration. ${ }^{d}$ Interaction between Type 2 diabetes duration and mean blood pressure. ${ }^{\mathrm{e}} x^{2}$ test for effect of mean blood pressure $(\mathrm{df}=2)$ derived from comparing this model with the model omitting both terms involving mean blood pressure. ${ }^{f}[(2 \times$ diastolic blood pressure) + systolic blood pressure $/ 3$. $g$ Analysed on a natural logarithmic scale

disease in each of these subjects was based on clinical judgement rather than a specific research protocol. Thus, unexplained clinically detectable albuminuria $(\geq 300 \mathrm{mg} / \mathrm{g}$ ) was found in $0.2 \%(4 / 1643)$ of subjects with normal and $1.2 \%(3 / 255)$ of those with impaired glucose tolerance.

The effect of glucose tolerance categories on abnormal albumin excretion ( $\geq 30 \mathrm{mg} / \mathrm{g}$ ), controlling for age, sex, and blood pressure, was examined using multiple logistic regression analysis (Table 2 ). When controlled for these variables and an interaction term between age and sex, the odds of abnormal albuminuria in subjects with impaired glucose tolerance were 1.5 times $(95 \%$ confidence interval, 1.0 to 2.2 ) those in subjects with normal glucose tolerance. The odds were even greater in subjects with diabetes compared with those with normal glucose tolerance. Diabetic men had odds of abnormal albuminuria 7.3 times (95\% confidence interval, 4.7 to 11.4 , controlled for age and mean blood pressure) those of men with normal glucose tolerance, and diabetic women had odds 4.0 times [ $95 \%$ confidence interval, 2.8 to 5.7 , controlled for age (with a quadratic term) and mean blood pressure] those of women with normal glucose tolerance. In each of these models, blood pressure was strongly associated with the prevalence of abnormal albuminuria.

The prevalence of abnormal albumin excretion among the diabetic subjects in relation to diabetes duration, blood pressure, $\mathrm{HbA}_{1}$, and insulin use were examined using multiple logistic regression analysis (Table 3). No difference in the frequency of abnormal albumin excretion was found between the sexes [odds ratio (men/women) $=1.0 ; 95 \%$ confidence interval, 0.7 to 1.4], but abnormal albumin excretion was significantly associated both with age and the duration of diabetes. In addition, abnormal albuminuria was positively associated with $\mathrm{HbA}_{1}$, mean blood pressure, and insulin treatment (when controlled for all other variables simultaneously). Body mass index (weight in $\mathrm{kg}$ /square of height in meters) and use of oral hypoglycaemic medicines did not contribute significantly to the model and were excluded from these analyses. Excessive albuminuria was more common in subjects treated with insulin (odds ratio $=1.9 ; 95 \%$ confidence interval, 1.2 to 3.0) and in those with higher $\mathrm{HbA}_{1}$. A $20 \%$ increment in $\mathrm{HbA}_{1}$, e.g., the difference between $10 \%$ and $12 \%$, was associated with an increased odds of excessive albuminuria (odds ratio $=1.3 ; 95 \%$ confidence interval, 1.2 to 1.5 ). Significant associations were also found when either fasting or $2 \mathrm{~h}$ post-load plasma glucose concentrations were used in place of $\mathrm{HbA}_{1}$.

Among the diabetic subjects, blood pressure was positively associated with abnormal albuminuria (Fig.3), but there was an interaction between mean blood pressure and diabetes duration which indicated that the association with blood pressure was stronger at longer durations of diabetes. The covariate-adjusted prevalence of abnormal albuminuria for subjects with mean blood pressures of $80 \mathrm{~mm} \mathrm{Hg}$ was $24 \%$ at 10 years and $42 \%$ at 20 years duration of diabetes; and for subjects with mean blood pressures of $120 \mathrm{~mm} \mathrm{Hg}$ was $67 \%$ at 10 years and $92 \%$ at 20 years duration of diabetes.

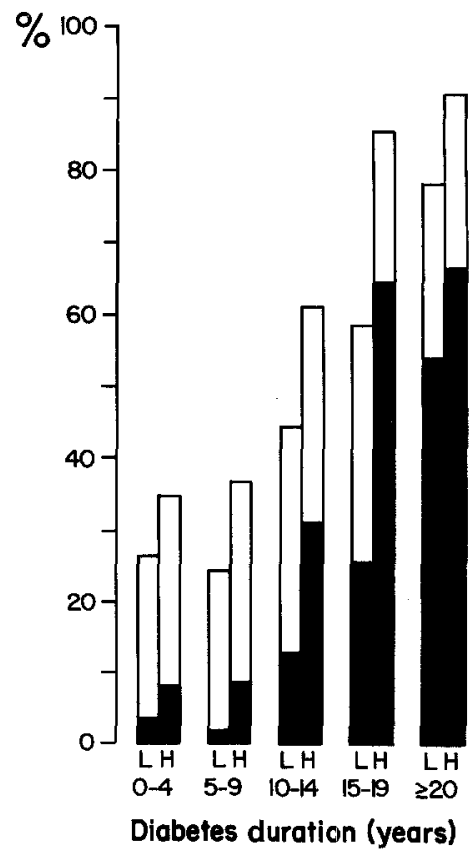

Fig.3. Prevalence (\%) of abnormal albuminuria in Type 2 (non-insulin-dependent) diabetic Pima Indians as a function of diabetes duration, according to low (L) or high $(\mathrm{H})$ mean blood pressure. The mean blood pressure was considered high if it was $\geq 95 \mathrm{~mm} \mathrm{Hg}$. Urine albumin/creatinine $(\mathrm{mg} / \mathrm{g})$ : 30-299 ( $\square)$; $\geq 300(\square)$ 


\section{Discussion}

Abnormal urinary albumin excretion was associated with the level of glycaemia in Pima Indians. Indeed, subjects with impaired glucose tolerance were found to have a higher prevalence of abnormal albuminuria than those with normal glucose tolerance. Keen et al. [32] have also reported higher albumin excretion rates in subjects who would now be considered to have impaired glucose tolerance. This suggests that hyperglycaemia below levels diagnostic of diabetes may be associated with renal dysfunction in some subjects. Although causes of abnormal albumin excretion, other than diabetes, were not systematically determined in this study, previous histologic examinations of the kidneys of Pima Indians show that intercapillary glomerulosclerosis associated with diabetes is the overwhelmingly predominant form of renal disease in the population [33]. Furthermore, $95 \%$ of the end-stage renal disease in Pima Indians occurs in those with diabetes, and among these, $97 \%$ are attributable to diabetic nephropathy [3].

The urinary albumin to creatinine ratio was used to assess albumin excretion in the present study. Several studies have shown a high degree of agreement between albumin excretion measured in this way and direct measurements of albumin excretion over a short timed collection period, and with overnight or 24-h urine collections [22-25]. Although there is intraindividual day to day variability in urine albumin excretion with coefficients of variation of about 45\% [34-38], the range of abnormality of particular interest in this study (30$299 \mathrm{mg}$ /day) is $2-20$ times the average normal albumin excretion. Thus, this large intraindividual day to day variation represents a relatively minor problem that would lead to group misclassification in only a small minority of the individuals. Such misclassification would reduce the strength of the associations that we have demonstrated.

An increased prevalence of abnormal albumin excretion has been found previously in persons with newly-diagnosed Type 2 diabetes compared with nondiabetic control subjects [39, 40]. Uusitupa et al. [39] found that $20 \%$ of newly-diagnosed Type 2 diabetic subjects in Finland had albumin excretion exceeding $35 \mathrm{mg} / 24 \mathrm{~h}$, whereas none of the non-diabetic subjects had excretion rates this high. Damsgaard and Mogensen [40] have reported that $26 \%$ of persons aged 60-74 years with occult fasting hyperglycaemia (fasting blood glucose $\geq 7.0 \mathrm{mmol} / 1$ and no history of diabetes) had albumin excretion rates greater than $30 \mu \mathrm{g} / \mathrm{min}$. Although occult fasting hyperglycaemia was associated with increased albuminuria only in men, known diabetes was associated with increased albuminuria in both men and women. Fabre et al. [41] found that 37\% of Type 2 diabetic subjects within a year of diagnosis in a Swiss outpatient clinic had protein excretion greater than $150 \mathrm{mg} / 24 \mathrm{~h}$.
The prevalence of abnormal albuminuria has also been determined in subjects with Type 1 and in those with Type 2 diabetes of longer duration. Parving et al. [42] found a prevalence of albuminuria ( $>30 \mathrm{mg} / 24 \mathrm{~h}$ ) of $41 \%$ in clinic patients with Type 1 diabetes of at least five years duration. The rate increased with duration but plateaued after 15 years of diabetes. This compares with a rate of $56 \%$ among the Type 2 diabetic subjects with at least five years duration in the present study, but in the Pima Indians the prevalence continued to increase past 20 years duration. Schmitz et al. [43] found that $35 \%$ of 329 Type 2 diabetic clinic patients from Denmark had abnormal albuminuria $(>15 \mu \mathrm{g} / \mathrm{min})$ compared with $47 \%$ of Type 2 diabetic Pima Indians who had albumin to creatinine ratios $\geq 30 \mathrm{mg} / \mathrm{g}$. Thus, the prevalence of abnormal albumin excretion in the Type 2 diabetic Pima Indians is at least as great as reported in Type 1 and other Type 2 diabetic populations.

$\mathrm{HbA}_{1}$, an integrated measure of the level of glycaemia, and fasting and $2 \mathrm{~h}$ plasma glucose concentrations were each associated with the prevalence of $a b$ normal albumin excretion among the Type 2 diabetic Pima Indians after controlling for confounding variables. Associations between glycaemia and albuminuria have also been found in several previous studies [38, 44-46]. In addition, insulin use was associated with albuminuria, possibly because insulin users had more severe hyperglycaemia.

A relationship between excessive albumin excretion and blood pressure has been described previously in non-diabetic subjects [40, 47] and in those with either Type 1 or Type 2 diabetes [32, 38, 44, 45, 48]. In the present study, higher mean blood pressure was associated with higher prevalence rates of abnormal albuminuria regardless of glucose tolerance. Among the diabetic subjects the relative difference in the frequency of abnormal albuminuria in relation to mean blood pressure was greater at longer durations of diabetes. The biological meaning of the relationship between blood pressure and diabetic renal disease, however, is difficult to assess in cross-sectional studies because elevated blood pressure may cause abnormal albumin excretion, but may also be a consequence of progressive diabetic renal disease. Mathiesen et al. [36] found that Type 1 diabetic subjects with normal urinary albumin excretion rates $(\leq 20 \mu \mathrm{g} / \mathrm{min}$ ) who progressed to incipient nephropathy (abnormal urinary albumin excretion rates $>70 \mu \mathrm{g} / \mathrm{min}$ ) developed significantly higher blood pressures than subjects who remained normal. In the Pima Indians, however, elevated blood pressure before the onset of diabetes has been shown to predict elevated albumin excretion after the onset of diabetes [49] and, in those with Type 2 diabetes, predicts the development of more severe proteinuria [2]. Thus, higher blood pressure seen in diabetic nephropathy is not entirely the result of the renal disease, but may precede and contribute to it. 
In the Pima Indians, proteinuria $(\geq 1 \mathrm{~g}$ protein $/ \mathrm{g}$ urine creatinine) predicts the development of renal insufficiency [2] and accounts for almost all of the excessive mortality related to diabetes [50]. The mortality rates from uraemia and cardiovascular diseases are significantly higher in diabetic persons with proteinuria than in those without [50]. Similar findings have been reported in subjects with Type 1 diabetes [51-53]. Whether or not levels of albumin excretion below those detectable by commonly used clinical methods predict the development of diabetic nephropathy or cardiovascular diseases in Pima Indians is not known. Subjects in the present study are being followed in order to address these questions. Mild elevations in albumin excretion, however, have been shown to predict the development of clinical proteinuria and mortality in non-Indian persons with Type 2 diabetes [6,54], and renal failure in those with Type 1 diabetes [5]. Furthermore, a relationship between albuminuria and cardiovascular disease has been reported in non-diabetic subjects [55] and in subjects with Type 2 diabetes [56].

In summary, abnormal albumin excretion not reliably detected by usual dipstick methods was commonly observed in diabetic Pima Indians, and was associated with age and increasing blood pressure regardless of glucose tolerance. Among those with diabetes, associations were found with age, duration of diabetes, level of glycaemia, blood pressure, and treatment with insulin. Furthermore, Pima Indians with impaired glucose tolerance, who have a high risk of developing diabetes [57], had a prevalence of abnormal albuminuria intermediate between subjects with normal glucose tolerance and those with diabetes. This suggests that hyperglycaemia below levels diagnostic of diabetes is associated with renal abnormalities in some subjects and that these abnormalities may even precede the onset of diabetes.

Acknowledgements. The authots are indebted to the members of the Gila River Indian Community for participating in this investigation and to the staff of the Diabetes and Arthritis Epidemiology Section and the Biostatistics and Data Management Section, NIDDK, for conducting the examinations and processing the data.

\section{References}

1. Friedman EA (1983) Nephrology forum. Diabetic nephropathy: strategies in prevention and management. Kidney Int 2 [Suppl]: 64-78

2. Kunzelman CL, Knowler WC, Pettitt DJ, Bennett PH (1989) Incidence of nephropathy in type 2 diabetes mellitus in the Pima Indians. Kidney Int 35:681-687

3. Nelson RG, Newman JM, Knowler WC, Sievers ML, Kunzelman CL, Pettitt DJ, Moffett CD, Teutsch SM, Bennett PH (1988) Incidence of end-stage renal disease in Type 2 (non-insulin-dependent) diabetes mellitus in Pima Indians. Diabetologia 31: 730-736

4. Hasslacher C, Michael C, Wahl P, Ritz E (1988) Risk of nephropathy in type II diabetes. Diabetes 37 [Suppl]: 242A (Abstract)

5. Viberti GC, Jarrett RJ, Mahmud U, Hill RD, Argyropoulos A, Keen H (1982) Microalbuminuria as a predictor of clinical nephropathy in insulin-dependent diabetes mellitus. Lancet I: 1430-1432

6. Mogensen CE (1984) Microalbuminuria predicts clinical proteinuria and early mortality in maturity-onset diabetes. $N$ Engl $J$ Med 310: 356-360

7. Parving H-H, Hommel E, Smidt UM (1988) Protection of kidney function and decrease in albuminuria by Captopril in insulin dependent diabetics with nephropathy. Br Med J 297: 1086-1091

8. Marre M, Chatellier G, Leblanc H, Guyene TT, Menard J, Passa P (1988) Prevention of diabetic nephropathy with Enalapril in normotensive diabetics with microalbuminuria. $\mathrm{Br}$ Med J 297: 1092-1095

9. Marre M, Leblanc H, Suarez L, Guyenne T-T, Ménard J, Passa $P$ (1987) Converting enzyme inhibition and kidney function in normotensive diabetic patients with persistent microalbuminuria. $\mathrm{Br}$ Med J 294: 1448-1452

10. Viberti GC, Pickup JC, Jarrett RJ, Keen H (1979) Effect of control of blood glucose on urinary excretion of albumin and $\beta_{2}$ microglobulin in insulin-dependent diabetes. $\mathrm{N}$ Engl $\mathrm{J}$ Med 300: 638-641

11. The KROC Collaborative Study Group (1984) Blood glucose control and the evaluation of diabetic retinopathy and albuminuria. $\mathrm{N}$ Engl J Med 311: 365-372

12. Parving H-H, Noer I, Deckert T, Ervin P-E, Nielsen SL, Lyngsøe J, Mogensen CE, Rørth M, Svendsen PAa, Trap-Jensen J, Lassen NA (1976) The effect of metabolic regulation on microvascular permeability to small and large molecules in short-term juvenile diabetics. Diabetologia 12: 161-166

13. Ciavarella A, Flammini M, Stefoni S, Borgnino LC, Forlani G, Bacci L, Vannini P (1982) Kidney function after improved metabolic control in newly diagnosed diabetes and in diabetic patients with nephropathy. Diabetes Care 5: 624-629

14. Vasquez B, Flock EV, Savage PJ, Nagulesparan M, Bennion LJ, Baird HR, Bennett PH (1984) Sustained reduction of proteinuria in Type 2 (non-insulin-dependent) diabetes following dietinduced reduction of hyperglycaemia. Diabetologia 26: 127133

15. Hommel E, Mathiesen E, Edsberg B, Bahnsen M, Parving H-H (1986) Acute reduction of arterial blood pressure reduces urinary albumin excretion in Type 1 (insulin-dependent) diabetic patients with incipient nephropathy. Diabetologia 29: 211-215

16. Knowler WC, Bennett PH, Bottazzo GF, Doniach D (1979) Islet cell antibodies and diabetes mellitus in Pima Indians. Diabetologia 17: 161-164

17. Knowler WC, Bennett PH, Hamman RF, Miller M (1978) Diabetes incidence and prevalence in Pima Indians: a 19-fold greater incidence than in Rochester, Minnesota. Am J Epidemiol 108: 497-505

18. Bennett PH, Burch TA, Miller M (1971) Diabetes mellitus in American (Pima) Indians. Lancet II: 825-828

19. World Health Organization (1985) Diabetes mellitus. Technical Report Series No 727, Geneva

20. Jaffe MZ (1886) Über den Niederschlag, welchen Pikrinsäure in normalen Harn erzeugt, und über eine neue Reaction des Kreatinins. Z Physiol Chem 10: 391-400

21. Chasson AL, Grady HJ, Stanley MA (1960) Determination of creatinine by means of automatic chemical analysis. Tech Bull Regist Med Techn 30: 207-212

22. Shaw AB, Risdon P, Lewis-Jackson JD (1983) Protein creatinine index and Albustix in assessment of proteinuria. Br Med $\mathrm{J} 287$ : 929-932

23. Ginsberg JM, Chang BS, Matarese RA, Garella S (1983) Use of single voided urine samples to estimate quantitative proteinuria. N Engl J Med 309: 1543-1546

24. Schwab SJ, Christensen RL, Dougherty K, Klahr S (1987) Quantitation of proteinuria by use of protein-to-creatinine ratios in single urine samples. Arch Intern Med 147: 943-944

25. Nathan DM, Rosenbaum C, Protasowicki VD (1987) Single-void urine samples can be used to estimate quantitative microalbuminuria. Diabetes Care 10: 414-418 
26. Technicon Autoanalyzer Method File N-20 (1965) Technicon Instruments Corporation, Tarrytown, New York

27. Menard L, Dempsey ME, Blankstein LA, Aleyassine H, Wacks M, Soeldner JS (1980) Quantitative determination of glycosylated hemoglobin $\mathrm{A}_{1}$ by agar gel electrophoresis. Clin Chem 26: $1598-1602$

28. Mantel N, Haenszel W (1959) Statistical aspects of the analysis of data from retrospective studies of disease. J Natl Cancer Inst 22: 719-748

29. Landis JR, Heyman ER, Koch GG (1978) Average partial association in three-way contingency tables: a review and discussion of alternative tests. Int Stat Rev 46: 237-254

30. Harrel FE (1983) The logist procedure. In: SAS Institute, Inc., SUGI Supplemental Library User's Guide. SAS Institute, Raleigh, North Carolina, pp 181-202

31. Lee J (1981) Covariance adjustment of rates based on the multiple logistic regression model. J Chronic Dis 34: 415-426

32. Keen H, Chlouverakis C, Fuller J, Jarrett RJ (1969) The concomitants of raised blood sugar: studies in newly-detected hyperglycemics. II. Urinary albumin excretion, blood pressure and their relationship to blood sugar levels. Guy's Hosp Rep 118: 247-254

33. Kamenetzky SA, Bennett PH, Dippe SE, Miller M, LeCompte PM (1974) A clinical and histologic study of diabetic nephropathy in the Pima Indians. Diabetes 23: 61-68

34. Gatling W, Knight C, Mullee MA, Hill RD (1988) Microalbuminuria in diabetes: a population study of the prevalence and an assessment of three screening tests. Diabetic Med 5: 343-347

35. Rowe DJF, Bagga H, Betts PB (1985) Normal variations in rate of albumin excretion and albumin to creatinine ratios in overnight and daytime urine collections in non-diabetic children. Br Med $\mathbf{J}$ 291: 693-694

36. Mathiesen ER, Oxenbøll B, Johansen K, Svendsen PAa, Deckert $\mathrm{T}$ (1984) Incipient nephropathy in Type 1 (insulin-dependent) diabetes. Diabetologia 26: 406-410

37. Chachati A, von Frenckell R, Foidart-Willems J, Godon JP, Lefèbvre PJ (1987) Variability of albumin excretion in insulindependent diabetics. Diabetic Med 4: 441-445

38. Cohen DL, Close CF, Viberti GC (1987) The variability of overnight urinary albumin excretion in insulin-dependent diabetic and normal subjects. Diabetic Med 4: 437-440

39. Uusitupa M, Siitonen O, Penttila I, Aro A, Pyörälä K (1987) Proteinuria in newly diagnosed type II diabetic patients. Diabetes Care 10: 191-194

40. Damsgaard EM, Mogensen CE (1986) Microalbuminuria in elderly hyperglycemic patients and controls. Diabetic Med 3: 430-435

41. Fabre J, Balant LP, Dayer PG, Fox HM, Vernet AT (1982) The kidney in maturity onset diabetes mellitus: a clinical study of 510 patients. Kidney Int 21: 730-738

42. Parving $\mathrm{H}-\mathrm{H}$, Hommel E, Mathiesen E, Skøtt P, Edsberg B, Bahnsen M, Lauritzen M, Hougaard P, Lauritzen E (1988) Prevalence of microalbuminuria, arterial hypertension, retinopathy and neuropathy in patients with insulin dependent diabetes. $\mathrm{Br}$ Med J 296: 156-160

43. Schmitz A, Vaeth M (1988) Microalbuminuria: a major risk factor in non-insulin-dependent diabetes. A 10-year follow-up study of 503 patients. Diabetic Med 5: 126-134
44. Gatling W, Mullee MA, Knight C, Hill RD (1988) Microalbuminuria in diabetes: relationships between urinary albumin excretion and diabetes-related variables. Diabetic Med 5: 348-351

45. Wiseman M, Viberti G, Mackintosh D, Jarrett RJ, Keen H (1984) Glycaemia, arterial pressure and microalbuminuria in Type 1 (insulin-dependent) diabetes mellitus. Diabetologia 26: 401-405

46. Mogensen CE (1976) Renal function changes in diabetes. Diabetes 25: 872-879

47. Parving $\mathrm{H}-\mathrm{H}$, Mogensen $\mathrm{CE}$, Jensen $\mathrm{H} A$, Evrin P-E (1974) Increased urinary albumin-excretion rate in benign essential hypertension. Lancet I: 1190-1192

48. Christensen CK, Mogensen CE (1985) The course of incipient diabetic nephropathy: studies of albumin excretion and blood pressure. Diabetic Med 2: 97-102

49. Knowler WC, Bennett PH, Nelson RG (1988) Prediabetic blood pressure predicts albuminuria after development of NIDDM. Diabetes 37 [Suppl]: 120 (Abstract)

50. Nelson RG, Pettitt DJ, Carraher MJ, Baird HR, Knowler WC (1988) The effect of proteinuria on mortality in non-insulindependent diabetes mellitus. Diabetes 37: 1499-1504

51. Andersen AR, Christiansen JS, Andersen JK, Kreiner S, Deckert T (1983) Diabetic nephropathy in Type 1 (insulin-dependent) diabetes: an epidemiological study. Diabetologia 25: 496-501

52. Borch-Johnsen K, Andersen PK, Deckert T (1985) The effect of proteinuria on relative mortality in Type 1 (insulin-dependent) diabetes mellitus. Diabetologia 28: 590-596

53. Jensen T, Borch-Johnsen $K$, Kofoed-Enevoldsen A, Deckert $T$ (1987) Coronary heart disease in young Type 1 (insulin-dependent) diabetic patients with and without diabetic nephropathy: incidence and risk factors. Diabetologia 30: 144-148

54. Jarrett RJ, Viberti GC, Argyropoulos A, Hill RD, Mahmud U, Murrells TJ (1984) Microalbuminuria predicts mortality in noninsulin-dependent diabetes. Diabetic Med 1: 17-19

55. Yudkin JS, Forrest RD, Jackson CA (1988) Microalbuminuria as predictor of vascular disease in non-diabetic subjects. Lancet II: $530-533$

56. Mattock MB, Keen H, Viberti GC, El-Gohari MR, Murrells TJ, Scott GS, Wing JR, Jackson PG (1988) Coronary heart disease and urinary albumin excretion rate in Type 2 (non-insulin-dependent) diabetic patients. Diabetologia 31: 82-87

57. Saad MF, Knowler WC, Pettitt DJ, Nelson RG, Mott DM, Bennett PH (1988) The natural history of impaired glucose tolerance in the Pima Indians. N Engl J Med 319: 1500-1506

Received: 26 April 1989

and in revised form: 16 August 1989

Dr. R.G. Nelson

Department of Biostatistics and Epidemiology

The Cleveland Clinic Foundation

1616 East Indian School Road

Suite 140

Phoenix, AZ 85016

USA 